\title{
The Assessment of Internal Audit Practices in Ethiopia (The Case of Finance and Economic Development Office in Adama City)
}

\author{
Zewdu Eskezia Gelaye \\ School of Business and Economics, Department of Accounting and Finance, Adama Science and Technology \\ University, Adama, Ethiopia
}

\begin{abstract}
The main objective of the study is to assess internal audit practice in finance and economic development office of Adama city. The researcher used descriptive type of research design and To achieve this objective the necessary data was collected from primary as well as secondary data sources, the primary data was collected from the target employees by using questionnaires and secondary data was obtained from manuals and related written materials and documents. From the company's five (5) departments the researcher selects two departments such as audit, inspection and payment and account in order to take sample of the research project. The raw data obtained from questionnaires was analyzed by using simple frequency tables. based on the findings of the study, the organization doesn't provide reasonable assurance regarding of prevention, or timely detection and correction of unauthorized acquisition, use or disposition of the entity's assets that could have a material effect on the financial statements, the company auditors doesn't involve in the activities of drafting policies and there is a problem around classification of performance deficiencies. Based on this finding the researcher recommends that the organization should give attention regarding to these problems and try to overcome in cooperation with the employees in order to perform a quality audit inspection within the organization.
\end{abstract}

Keywords: Internal audit, audit quality, competency, independence, audit planning

DOI: $10.7176 / \mathrm{RJFA} / 10-17-03$

Publication date:September $30^{\text {th }} 2019$

\section{Introduction}

\subsection{Background of the Study}

Auditing is an objective, systematic and independent examinations of accounts which is conducted by professionally qualified person. (Arens, 1997)

Auditing can be simply classified as internal and external auditing. The common definition of auditing is a systematic process of objectively obtaining and evaluating evidence regarding assertions about economic actions and events to ascertain the degree of correspondence between those assertions and established criteria and communicating the result to interested users. (Konra, 1999)

Prior to 1941, internal auditing was essentially a clerical function because much of record keeping at that time was performed manually. auditors were needed to the accounts of records after it were completed in order to locate errors, the old concept of internal audit can be compared with a form of insurance that the major objectives of it was discovering fraud. (Spener, 2010)

Internal auditing is essentially an appraisal activity within the organization for the review of accounting operation method and procedure, financial and other operations of the organization by measuring and evaluating efficiency and effectiveness of the organization. Auditing is an import ant managerial control device (Doug, 2010).

The starting place for internal audit theory is the definition of internal audit. The divergence and interpretation of the audit role is explored, in terms of the way we may practice more average from the standard its own approach and style. The institution of internal auditors (IIA) definition internal auditing is an independence objective assurance, and consulting activity designed to add value and Importance to an organization's operation. It helps an organization to accomplish its objectives by bringing a systematic way of risk management, control and governance process. (Spencer, 2010)

Internal auditing refers to an independent appraisal of the activity within the organization for the review of accounting, financial and other operations and activities by stuff of auditors function as part of the management and reporting to it and not to the shareholders. According to the institute of internal auditors USA internal auditing is an independent appraisal function established within an organization to examine and evaluate its activities as a service to the organization. (Basus, 2010)

\subsection{Statement of the Problem}

In recent years, researchers and practitioners have widely discussed the need for internal auditors of adding more value to their companies operation and contributing to the achievement of corporate objectives. According to 
Orma et al, (2012) this study was focused on increasing attention on issues such as; performance evaluation and effectiveness of the company's internal auditing. Companies employ their own internal auditors to do both financial and operational audits. Internal auditors focus on different areas. But the extent of internal auditing may vary from one company to another (arenas etal, 2012)

The most important factors which affects the effectiveness of internal auditing practices of finance and economic development office are; lack of strong internal control over financial reporting, absence of proper follow up procedures (implementing) audit recommendation, lack of better use of new technology, work load on individual auditors and improper position of auditors according to the scholar Orma et al, (2012).

There are to many studies that are done in different parts of the world related with this title. But any of one up to the researcher's knowledge is not done in this area so, the researcher intends to do this study in order to fill the gap by using the combination of five main variables such as internal audit quality, internal control system of the organization, management control system, audit planning and audit independence.

And to come up with this; the researcher answers the following basic research question.

- What are the internal audit qualities of the organization?

- How effective is the internal control system of the organization over financial reporting?

- How the management controls the audit quality of the organization?

- How internal audit offices prepare audit planning?

- How the applicability of independency is determined in the organization?

In line with the above research questions the researcher develops the following general and respective specific objectives.

The general objective of the study was to assess the internal audit practices of finance and economic development office of Adama city.

A care full review of the main objective leads to develop the following specific objectives.

To know internal audit quality of the organization

- To assess the effectiveness of internal control system of the organization over financial reporting

- To assess how the management controls the audit quality of the organization

- $\quad$ To assess and evaluate internal audit plan of the organization

- $\quad$ To assess the professional independency of auditors in the organization.

\section{Methodology of the Study}

\subsection{Research Design}

The research design employed in this study was descriptive type of research design.

Descriptive type of research design is a type of research design which directly describes the situation of some specific process. Gorge Morales, (2014) and it was employed in this research in order to describe internal auditing practice of finance and economic development office of Adama city analytically.

\subsection{Target Population}

This research was conducted to assess the internal audit practices of finance and economic development office of Adama city. In the organization there are total employees of 64 . From these 41 of them are employed in auditing and payment and accounting departments and those 41 employees become the target population of the study.

\subsection{Sampling techniques}

Sampling is the process of choosing sample from a large population which used to make generalized statement. Leedey, (1998)

The method of sampling technique used in this study was judgmental type of non probability sampling and census. Judgmental sampling technique was selected to take samples from payment and accounting department. This technique was selected in order to get a better and accurate data from those employees who are professional in the field of the study. Census was selected due to the small number of audit department employees and to take all of them as a sample.

\subsection{Sample Size}

Adama finance and economic development office has 41 employees in auditing and payment and accounting departments. To this research project the researcher takes 14/35 from payment and accounting (40\%) of them and 6/6 from auditing department. (100/\% of them) which constitute a total of 20 samples was selected judgmentally and censuses

\subsection{Type and Source of Data}

The researcher used both primary and secondary sources of data in order to get realistic data. The primary data was collected from the company's management, auditing payment and accounting departments by using 
unstructured interview and questionnaires.

And the secondary data was obtained from information pertaining to the company and its internal auditing practice, from the company's manual and reports, books and other various valuable materials.

\subsection{Method of Data Collection}

The required data for the research was collected by using both open ended and close ended questionnaires.

\subsection{Methods of Data Analysis}

The collected data was tabulated, organized, analyzed and interpreted to draw sound conclusion and valid generalization. And to do these the researcher uses both qualitative and quantitative methods of data analysis. Quantitative data analysis was used in order to discover inherent facts and explore new facts.

Qualitative data analysis was used to provide depth and detail answers o research questions through direct quotation and full description to explore new facts or to re-interpret already known existing facts.

\section{Results and Discussions}

The data obtained from the various categories of respondents with the help of chosen instruments would be presented and discussed in this chapter.

Table 4:1 Background of Respondents

\begin{tabular}{|c|c|c|c|c|}
\hline & & & Respond & \\
\hline No. item & Item & Description & Number & Percent $\%$ \\
\hline 1 & Sex & Mal & 12 & $75 \%$ \\
\hline & & Female & 4 & $25 \%$ \\
\hline & & Total & 16 & $100 \%$ \\
\hline & & Diploma & 0 & $0 \%$ \\
\hline 2 & & Degree & 16 & $100 \%$ \\
\hline & Education status & MA .degree & 0 & $0 \%$ \\
\hline & & Other & 0 & $0 \%$ \\
\hline & & Total & 16 & $100 \%$ \\
\hline 3 & & $<1$ year & 0 & $0 \%$ \\
\hline & experience in the & $1-5$ years & 4 & $25.0 \%$ \\
\hline & organization & $6-10$ years & 4 & $25 \%$ \\
\hline & & $>10$ years & 8 & $50 \%$ \\
\hline & & Total & 16 & $100 \%$ \\
\hline
\end{tabular}

Source; questionnaires 2019

As it is shown on the above table 4.1; most of the respondents $12(75 \%)$ of them are males and the remaining $4(25 \%)$ are females. from the above table one can understand that most of the company's internal auditing practices are performed by males than females.

As indicated on the above table (table,4.1) none of the respondents are above and below degree level that is $16(100 \%)$ of the respondent are degree holders. from this one can under stood that the company's internal auditing practice is performed by degree holders.

From the total respondents; (table, 4.1): 8 (50\%) of employees had a work experience of greater than 10 years, $4(25 \%)$ of them had an experience of $6-10$ years and $4(25 \%)$ of the employees have an experience of $1-5$ years. Therefore most employees are experienced more than 5 years. The organization had good potential to improve its performance. Because it has well experienced employees

\section{B. Evaluation of Internal Audit Practice}

To measure the auditor's ability to properly plan, perform and communicate audit results, the researcher raised the following two questions.

Table 4:2Auditors Capability to Audit

\begin{tabular}{|l|l|l|l|}
\hline Description & Item & \multicolumn{2}{l|}{ Respondents response } \\
\cline { 3 - 4 } & & $\begin{array}{l}\text { Frequency } \\
\text { (number) }\end{array}$ & $\begin{array}{l}\text { Percent } \\
(\%)\end{array}$ \\
\hline $\begin{array}{l}\text { Do the company auditors arrive at a useful finding and } \\
\text { forwards recommendation for improvement? }\end{array}$ & Yes & 6 & $37.5 \%$ \\
\hline & NO & 10 & $62.5 \%$ \\
\hline $\begin{array}{l}\text { Do the auditors have the ability to properly plan, } \\
\text { perform and communicate audit results? }\end{array}$ & Total & 16 & $100 \%$ \\
\hline & Yes & 9 & $56.25 \%$ \\
\hline
\end{tabular}

Source; questionnaires 2019 
According to the employees response shown in the above table ' 4.2 ' $6(37.5 \%)$ of them replied that auditors in the company arrives at a useful finding and forward recommendation for improvement. And $62.5 \%$ (10) of the respondents replied that auditors in the company doesn't arrive at useful finding and forward recommendation due to the reason that most of the employees empowered only by experience. That is from lower position to auditing randomly only by attending in distance and private colleagues. And this leads low quality of audit inspection in the company.

From table ' 4.2 ' above we can also look that 9 (56.25\%) of the respondents replied that internal auditors of the company have the capability to proper plan perform and communicate audit results but 7 (43.75) of them responded that due to the auditors in proper position. they have not the ability to properly plan ,perform and communicate audit results.

From this as the raised questions are the measures of internal auditor's capability to audit, the researcher under stood that the organization auditors haven't enough capability to audit because of their improper position.

Table 4:3 Audits Planning In the Company

\begin{tabular}{|l|l|l|l|}
\hline Description & Item & Respondents response \\
\hline & & Number & Percent \% \\
\hline \multirow{2}{*}{$\begin{array}{l}\text { Dose the organization prepare } \\
\text { strategic }\end{array}$} & Yes & 16 & $100 \%$ \\
\cline { 2 - 4 } Adult plan? & No & 0 & 0 \\
\cline { 2 - 4 } $\begin{array}{l}\text { Dose the organization prepare } \\
\text { periodic (annual) audit plan? }\end{array}$ & Total & 16 & $100 \%$ \\
\cline { 2 - 4 } & Yes & 16 & $100 \%$ \\
\cline { 2 - 4 } & Total & 0 & 0 \\
\hline \multirow{2}{*}{$\begin{array}{l}\text { Dose the organization prepare } \\
\text { plan for individual audit } \\
\text { assignments }\end{array}$} & Yes & 16 & $100 \%$ \\
\cline { 2 - 4 } & Total & 0 & $100 \%$ \\
\hline
\end{tabular}

Source; questionnaires 2016

According to table 4.3 above: $16(100 \%)$ of the respondents replied that the internal audit department prepares all the three types of audit planning, Which are; strategic, annual and plan for individual adult assignments? As result the researcher understands that the organization had a good internal audit quality interim of planning. Since audit plan is a vital activity for effectiveness of internal auditing practice which can add value of the organization.

\section{Table4:4 Segregation of Duties}

\begin{tabular}{|l|l|l|l|}
\hline Description & Item & \multicolumn{2}{|l|}{ Respondents response } \\
\hline $\begin{array}{l}\text { Is proper segregation of duties in the company for the activation of } \\
\text { - Record keeping }\end{array}$ & Yes & 16 & $100 \%$ \\
$\begin{array}{l}\text {-payment and receipt } \\
\text {-financial statement } \\
\text {-preparation and } \\
\text {-audit purchase and budget? }\end{array}$ & No & 0 & 0 \\
\hline & & & \\
\hline
\end{tabular}

Source; questionnaires 2019

As shown on the above table ' 4.4 ' $16(100 \%)$ of the respondents replied that there is a proper segregation of duties in the organization. according to the respondents, internal control in the organization is good since the segregation of duties enable to check and balance. That is no one handles all aspects of transaction from beginning to end. In case the practice of internal audit of the organization is good hence it had good internal control. 
Table4: 5 the Organization Internal Control Over Financial Reporting

\begin{tabular}{|c|c|c|c|}
\hline \multirow[t]{2}{*}{ Description } & \multirow[t]{2}{*}{ Item } & \multicolumn{2}{|c|}{ Respondents response } \\
\hline & & Number & Percent $\%$ \\
\hline \multirow{3}{*}{$\begin{array}{l}\text { Does the organization provide assurance that maintains records in } \\
\text { reasonable detail, accuracy, and fairly reflect transaction and disposition of } \\
\text { assets? }\end{array}$} & Yes & 10 & $62.5 \%$ \\
\hline & No & 6 & $37.5 \%$ \\
\hline & total & 16 & $100 \%$ \\
\hline \multirow{3}{*}{$\begin{array}{l}\text { Does it provide assurance that transactions are recorded and financial } \\
\text { statements are prepared in accordance with the reporting frame work? }\end{array}$} & yes & 12 & $75 \%$ \\
\hline & no & 4 & $25 \%$ \\
\hline & total & 16 & $100 \%$ \\
\hline \multirow{3}{*}{$\begin{array}{l}\text { Does it provide reasonable assurance regarding prevention, or timely } \\
\text { detection, and correction of un authorized acquisition, use or disposition of } \\
\text { the entity's assets that could have a material effect on the financial } \\
\text { statement? }\end{array}$} & Yes & 5 & $32.25 \%$ \\
\hline & No & 11 & $68.75 \%$ \\
\hline & Total & 16 & $100 \%$ \\
\hline
\end{tabular}

Source; questionnaires 2019

As shown on the above table (table 4.5), the researcher raised 3 questions to sample of the research which are the measure of the organization's internal control system over financial reporting.

The respondents $10(62.5 \%)$ responses that the organization maintains records in reasonable detail, accuracy and fairly reflects transaction and disposition of assets of the entity . whereas the rest $6(37.5 \%)$ of them responded that the organization doesn't maintain records in reasonable detail, accuracy due to the reason that no better use of new technology and proper follow up procedures.

According to the second question (table 4.5): most of the respondents $12(75 \%)$ replied that the organization provides assurance that transactions are recorded and financial statements are prepared in accordance with the reporting frame work and the rest $4(25 \%)$ of the respondents revealed that the organization doesn't provide assurance that transaction are recorded and financial statement are prepared in accordance with the reporting frame work.

According to table 4.5 (question three): most of the respondent 11 (68.75) responds that the organization doesn't provide reasonable assurance regarding of prevention, or timely detection and correction of unauthorized acquisition, use or disposition of the entity's assets that could have a material effect on the financial statements. And the reason behind is that as obtained from unstructured interview result, due to the work load on individual work unit and no better use of new technology.

As all the above three question are measures of the organization's internal control over financial reporting the researcher under stood that the organization internal control over financial reporting is medium ,based on the respondents response. As a result: internal auditing practice of the organization is medium which is not effective, since internal audit practice significantly affects the organization's internal control over financial reporting system.

Table4:6 Internal Auditors' Quality

\begin{tabular}{|l|l|l|l|}
\hline \multirow{2}{*}{ Description } & Item & \multicolumn{2}{l|}{ Respondents response } \\
\cline { 2 - 4 } & & Number & Percent $\%$ \\
\hline \multirow{2}{*}{ Do internal auditors conduct internal control training? } & Yes & 16 & $100 \%$ \\
\cline { 2 - 4 } & No & 0 & 0 \\
\hline & Total & 16 & $100 \%$ \\
\hline \multirow{2}{*}{$\begin{array}{l}\text { Do they provide advice to management about control } \\
\text { concerns in new system? }\end{array}$} & Yes & 14 & $87.5 \%$ \\
\cline { 2 - 4 } & No & 2 & $12.5 \%$ \\
\hline \multirow{2}{*}{$\begin{array}{l}\text { Dose the company auditors involve in the activity of } \\
\text { drafting policies? }\end{array}$} & Total & 16 & $100 \%$ \\
\hline & Yes & 3 & $18.75 \%$ \\
\hline & No & 13 & $81.25 \%$ \\
\hline
\end{tabular}

Source; questionnaire 2019

In the above table ' $4.6^{\prime}$; the researcher raises three types of activities that a capable auditor should participate or involve in consulting activities. Most of the respondents (all of the respondents) replied that the company auditors involve in the activities of conducting internal control training and most of them 14 (87.5) responds that the company auditors provide advice to management about the control concerns in new system. but the rest $2(12.5 \%)$ of them revealed that the company auditors didn't involve in providing advice to the management about the control concerns in new system due to the individual auditors work load and in effectiveness.

According to the above table '4.6' most of the respondents replied that the company auditors doesn't 
involve in the activities of drafting policies. Because as obtained from unstructured interview finance and economic development offices are one of the public organizations; most of the time drafting policies exists at bureau of finance and economic development at the woreda level.

Based on the data on the above table the researcher understands that Adama finance and economic development office auditors involve in consulting activities which they must participate in and this is essential to the organization effectiveness of auditing practice and can also add value to the organization.

Table 4:7internal Auditors' Quality

\begin{tabular}{|l|l|l|l|}
\hline Description & Item & \multicolumn{2}{l|}{ Respondents response } \\
\hline & & Number & Percent $\%$ \\
\hline $\begin{array}{l}\text { Do the company auditors involve in the following types of audit? } \\
\text { - financial statement audit } \\
\text { - operational audit } \\
\text { - Compliance audit }\end{array}$ & Yes & 15 & $93.75 \%$ \\
\hline & No & 1 & $6.25 \%$ \\
\hline
\end{tabular}

Source; questionnaire 2019

As shown in the above table '4.7' most of the respondents 15(93.75\%)are agreed or responds that the company auditory involve or performs the three types of audits which are; financial statement audit, operational audit and compliance audit. from the total respondent $1(6.25 \%)$ of them responds that the company auditors doesn't involve in the three types of audits.. due to the reason that the work load of individual audits they didn't much in operational audit of the company.

As the response of the respondents; the company auditors' scope of activity is appreciable. It makes the internal auditing practice of the organization good. Because they performs all the necessary types of audit

Table4: 8 Independence And Objectivity of Internal Auditors

\begin{tabular}{|c|c|c|c|}
\hline Description & Item & Respond & \\
\hline \multirow{4}{*}{$\begin{array}{l}\text { Does internal auditors free from personal } \\
\text { and external impairments? }\end{array}$} & & Number & Percent $\%$ \\
\hline & Yes & 16 & $100 \%$ \\
\hline & No & 0 & 0 \\
\hline & Total & 16 & $100 \%$ \\
\hline \multirow{3}{*}{$\begin{array}{l}\text { Doses the company auditor's independent } \\
\text { in fact and appearance? }\end{array}$} & Yes & 10 & $62.5 \%$ \\
\hline & No & 6 & $37.5 \%$ \\
\hline & Total & 16 & $100 \%$ \\
\hline \multirow{3}{*}{$\begin{array}{l}\text { Don't they subordinate their judgment on } \\
\text { audit matters to others? }\end{array}$} & Yes & 16 & $100 \%$ \\
\hline & No & 0 & 0 \\
\hline & Total & 16 & $100 \%$ \\
\hline
\end{tabular}

Source; questionnaires 2019

To become objective and independent, an auditor should posses the following characteristics: Auditors should free from personal and external imperilments, independent in fact and appearance and they should not subordinate their Judgment on audit matters to others.

Based on these measurements, the researcher measures the company auditor's objectivity and independence by raising the measurement criteria as a question to the respondents.

According to the above table 4.8; all of the respondents replied that $16(100 \%)$ of them. internal auditors are free from personal and external impairments and $10(62.5 \%)$ of them also responds that the company auditors are independent in fact and appearance, but 6(37.5\%) of them responds that Adama finance and economic development office auditors are independent in fact. But they are not independent in appearance. And the reason is that due to working environment condition and the company employees' relationship. And for the third (3) raised question; all of the respondents $16(100 \%)$ agrees that the company auditors didn't subordinate their judgment on audit matters to others.

From these the researcher understands that in Adama finance and economic development office internal auditors are independent and objective; and the auditors objectivity and independence is essential to the effectiveness of internal auditors function which adds value to the organization 
Table4:9 Compliance with Policies and Procedures

\begin{tabular}{|c|c|c|c|}
\hline \multirow[t]{2}{*}{ Description } & & \multicolumn{2}{|c|}{ Respondents response } \\
\hline & & Number & Percent $\%$ \\
\hline \multirow{3}{*}{$\begin{array}{l}\text { Does the company follow budget preparation policies and procedures } \\
\text { applied to the public sector? }\end{array}$} & Yes & 10 & $62.5 \%$ \\
\hline & No & 6 & $37.5 \%$ \\
\hline & Total & 16 & $100 \%$ \\
\hline \multirow{3}{*}{$\begin{array}{l}\text { Does the organization follow purchasing policy which is applied in the } \\
\text { public sector? }\end{array}$} & Yes & 9 & $56.25 \%$ \\
\hline & No & 7 & $43.75 \%$ \\
\hline & Total & 16 & $100 \%$ \\
\hline \multirow[t]{3}{*}{ Dose the company applies information disclosure policy? } & Yes & 15 & $93.75 \%$ \\
\hline & No & 1 & $6.25 \%$ \\
\hline & Total & 16 & $100 \%$ \\
\hline \multirow[t]{3}{*}{ Dose the organization follow personnel utilization policy? } & Yes & 16 & $100 \%$ \\
\hline & No & 0 & 0 \\
\hline & Total & 16 & $100 \%$ \\
\hline
\end{tabular}

Source; questionnaire 2019

As shown on the above table ' 4.9 ' the researcher raises a list of policies and procedures that are applied in the public sector. And most of the respondent respond that Adama finance and economic development office applies the following policies and procedures, budget preparation, purchasing, information disclosure policy and personnel utilization policy with the respectively $10(62.5 \%), 9(56.25 \%), 15(93.75 \%)$ and 16(100\%). And the rest of the respondents didn't agree and the reason is that all of the procedures and policies are not applied in the organization due to time and work load of the employees as obtained from unstructured interview result.

From the respondents; the researcher understands that Adama finance and economic development office follows policies and procedures or the organization performs its activities in compliance with policies and procedures and this activity leads or adds value to the internal audit practice effectiveness.

Table 4: 10 Responsibly Of Auditors to Detect Misstatements

\begin{tabular}{|c|c|c|c|}
\hline \multirow[t]{2}{*}{ Description } & \multirow[b]{2}{*}{ Item } & \multicolumn{2}{|c|}{ Respondents Response } \\
\hline & & Number & percent \\
\hline \multirow{5}{*}{$\begin{array}{l}\text { Do the company auditors verify financial statements assertion when } \\
\text { misstatements exist by Appling the following methods? } \\
\text { - } \quad \text { By comparing information on the received report to the purchase } \\
\text { journal } \\
\text { evidence such as paid checks } \\
\text { by comparing the general ledger account cash in bank with the } \\
\text { bank statement. }\end{array}$} & Yes & 16 & $100 \%$ \\
\hline & No & 0 & \\
\hline & & & \\
\hline & & & \\
\hline & & & \\
\hline & Total & 16 & $100 \%$ \\
\hline
\end{tabular}

Source; questionnaires 2019

On the above table ' 4.10 ', all the respondents $16(100 \%)$ replied that internal auditors verify financial statement assertions when misstatement exists since the auditors are required to prepare audit reports and they are taking responsibilities for the report they made, they certify financial statement assertion by comparing the information on the received report to the purchase journals, comparing recorded purchase transaction in the purchase journal to supporting evidence such as, paid checks and re concealing the general ledger account cash in bank with the bank statement. 
Table 4: 11internal audit department's follow up procedures

\begin{tabular}{|c|c|c|c|}
\hline \multirow{2}{*}{ Description } & \multirow[t]{2}{*}{ Item } & \multicolumn{2}{|c|}{ Respondent response } \\
\hline & & Number & Percent $\%$ \\
\hline \multirow[t]{3}{*}{ Does the company identify the required performance level? } & Yes & 11 & $68.75 \%$ \\
\hline & No & 5 & $31.25 \%$ \\
\hline & total & 16 & $100 \%$ \\
\hline \multirow{3}{*}{$\begin{array}{l}\text { Dose the company determine whether or not performance } \\
\text { deficiencies exist? }\end{array}$} & Yes & 12 & $75 \%$ \\
\hline & No & 4 & $25 \%$ \\
\hline & total & 16 & $100 \%$ \\
\hline \multirow[t]{3}{*}{ Dose it classify performance deficiencies? } & Yes & 9 & $56.25 \%$ \\
\hline & No & 7 & $43.75 \%$ \\
\hline & total & 16 & $100 \%$ \\
\hline \multirow[t]{3}{*}{ Dose it develop corrective action plan? } & Yes & 16 & $100 \%$ \\
\hline & No & 0 & 0 \\
\hline & total & 16 & $100 \%$ \\
\hline \multirow[t]{3}{*}{ Dose the organization evaluate the success of corrective action? } & Yes & 10 & $62.5 \%$ \\
\hline & No & 6 & $37.5 \%$ \\
\hline & total & 16 & $100 \%$ \\
\hline
\end{tabular}

In any organization internal audit departments should follow the following procedures to insure whether corrective action is taken as per recommendation; such as; identify the required performance level, determine whether or not performance deficiencies exist, Classify performance deficiencies, develop corrective action plan and evaluate the success of corrective action.

As shown on the above table'4.11 Adama finance and economic development office follows the listed procedures as most of the respondent replied.

The respondents percentage with respectively to the order of the procedures as most are 11(68.75\%), $12(75 \%), 9(56.25 \%), 16(100 \%), 10(62.5 \%)$. and the rest responds that Adama finance and economic development office internal audit departments doesn't follow all the procedures listed on the above. According to the result of unstructured interview; the reason that the auditors do not follow all the listed procedures is due to that the recurring nature of the work and negligence of employees.

As major of the respondent signified; the internal audit department Adama finance and economic development office has formal follow up procedures that could help in some extent to enhance the quality of audit. For this reason the internal audit of the organization follow up procedures is good since it has some extent of good management support as obtained from unstructured interview result and this can improve the effectiveness of internal audit practice within the organization but there is a problem around classification of performance deficiencies.

Table4:12Audit Performance of the Organization

\begin{tabular}{|l|l|l|l|}
\hline Description & Item & \multicolumn{2}{l|}{ Respondents response } \\
\cline { 3 - 4 } & & Number & Percent $\%$ \\
\hline How the past three years audit performance as compared to & Excellent & 1 & $6.25 \%$ \\
\cline { 2 - 4 } $\begin{array}{l}\text { current year in terms of the following criteria? } \\
\text { - Staff experience }\end{array}$ & Good & 11 & $68.75 \%$ \\
\cline { 2 - 4 } $\begin{array}{l}\text { - percentage of audit recommendation } \\
\text { - auditors education level }\end{array}$ & Satisfactory & 3 & $18.75 \%$ \\
\hline & Poor & 1 & $6.25 \%$ \\
\hline
\end{tabular}

Source; questionnaires 2019

As shown on the above table' 4.12 ' $1(6.25 \%), 11(68.25 \%), 3(18.75 \%)$ and $1(6.25 \%)$ of the respondent replied that the audit performance of the last three(3) years when compared to the current year was excellent, good, satisfactory and poor respectively with the percentages. As a result audit result of the last three years as compared to the current year was good and this implies or indicates the current year performance of the organization. 
Table 4:13Preparation of Audit Report

\begin{tabular}{|l|l|l|l|}
\hline Description & Item & \multicolumn{2}{l|}{ Respondent } \\
\cline { 3 - 4 } & & Number & Percent $\%$ \\
\cline { 3 - 4 } & monthly & 5 & $31.25 \%$ \\
\hline $\begin{array}{l}\text { For how long the finance and economic development office } \\
\text { prepare audit report? }\end{array}$ & quarterly & 10 & $62.5 \%$ \\
\cline { 2 - 4 } & semiannually & 1 & $6.25 \%$ \\
\cline { 2 - 4 } & annually & 0 & 0 \\
\hline & Total & 16 & $100 \%$ \\
\hline
\end{tabular}

Source; questionnaires 2019

As indicated on the above table ' 4.13 ' the office of finance and economic development in Adama town prepares audit report monthly, quarterly and semi annually with the respondent responses percentage as the following respectively $5(31.25 \%), 10(62.5 \%), 10(62.5 \%)$ and $1(6.25 \%)$.

Thus most respondents clearly stated that audit report is prepared on quarterly basis monthly and quarterly basis of audit reports are advisable and improved effectiveness of internal control. And this improves effectiveness of internal audit practice.

Table 3:14 Financial Analyses in Internal Audit Practice

\begin{tabular}{|l|l|l|l|}
\hline Description & Item & \multicolumn{2}{l|}{ Respondent response } \\
\hline \multirow{2}{*}{$\begin{array}{l}\text { How the organizations make financial } \\
\text { analysis in order to assist internal }\end{array}$} & -by using comparative analysis method & 12 & $75 \%$ \\
\cline { 2 - 4 } auditing practice? & -by ratio analysis method & 2 & $12.5 \%$ \\
\cline { 2 - 4 } & -by trend analysis method & 2 & $12.5 \%$ \\
\hline
\end{tabular}

Source; Questionnaires 2019

From the above table ' 4.14 ' $12(75 \%)$ of the respondents replied that Adama finance and economic development office make financial analysis by using comparative method of analysis and 2(12.5\%)of the respondent replayed that the organization uses ratio analysis method. and the rest $2(12.25 \%)$ replied that the organization uses trend analysis method.

From these the researcher understands that Adama finance and economic development office makes financial analysis by using comparative financial analysis method. As comparative method of financial analysis an effective method; it will assist the internal audit practice effectiveness.

\section{Conclusions and recommendations}

\subsection{Conclusions}

As known internal auditing is the most important activity within the organization for reviewing of accounting, financial and other operations of the organization (Douglas, 2010). Therefore the main objectives of the study were to assess the internal audit practice effectiveness and efficiency in finance and economic development office of Adama city.

Based on the above analysis the following conclusions can be drawn by identifying the problems of internal auditing practice.

The researcher distributed a well designed questionnaires to those the organization employees who are selected as sample judgmentally and census.

As the result of the finding internal audit practices in the organization is an objective assurance, independent and participates in the consulting activities designed to add value and improve organization operations

Therefore it adds value by performing, effective internal auditing in the areas of audit planning, scope of the audit service, performing the activities in compliance with policies and procedures maintain segregation of duties, prepare audit report quarterly that is important to determine effective control and independence of internal auditors.

The organization internal control system over financial reporting and audit quality is medium. There is no proper follow up (implementing) audit recommendation and this can minimize the effectiveness of internal audit practices that reduce the ability of add value to the organization. In addition the organization auditors are not qualified for their position,work load on individual auditors due to no better use of new technology ,and this leads the auditors don't follow up procedures and minimizes there detail substantive testing.

\subsection{Recommendation}

This study was conducted in order to assess the practice of internal auditing practices in Adama finance and economic development office and forward possible recommendations based on the findings of the study; the researcher forwards constructive suggestions and recommendation in the hope of that they would be alleviate and improve. 
The organization has medium internal audit quality and there is no proper follow up (implementation) of audit recommendations. This activity minimizes the effectiveness of internal audit incase reduces the ability to add value for the organization. therefore; the internal audit practices of the organization needs an improvement in this area for effective practice of internal audit to add value the organization must hire employees that are qualified in internal auditing practice, and this will enhance the quality of internal audit and proper follow up of audit recommendations.

The internal auditors in the organization are not qualified for their position because of the rank given for the position of internal audit officers are low, most internal auditors are accounting graduates in private colleagues most of the time by distance and extension programs. As a result they didn't utilize efficiently and effectively the practice of auditing and this will have an effect on internal audit practice. So, the manager should take a great concern about internal auditor's qualification.

There is no better use of new technology application; and these results in most of the activities performed manually. This leads increment for the individual auditors work load and in efficient for proper time utilization. The organization must consider this problem; because today every work goes with technology improvement and will increase the effectiveness of the internal audit practice. To overcome workloads on individual work units and to use work times efficiently; new technology should be applicable in the organization.

The organization has less training program in the practice of internal auditing and then the manager should consider this issue too; and must give training program to the employees.

\section{References}

Andrew Chamber (1992) Internal Auditing, $3^{\text {rd }}$ Edition, United Kingdom. Arenas et al., (2012) Auditing And Assurance Service, 14th Edition United States.

Ann Swayey. (1992). Internal Auditing, $14^{\text {th }}$ edition, India.

Arenas et al, (2006), Managerial Auditing $17^{\text {th }}$ Edition .United Kigdom.

Arenas et al, (2006) Managerial Auditing $17^{\text {th }}$ Edition, United Kigdom

Johaneskinfu and Ingida Bayou, (2009).Auditing Introduction to Principle and Practice. Ethiopia.

KH Speneer, (2003), Internal Auditing Hand Book, $3^{\text {rd }}$ Edition, India

Dessalegn getie and Aderajew wondim, (2007), Managerial Auditing Jour Volume, 22 Ethiopia.

Dhumbeetal, (2004), Cost Auditing and Management $3^{\text {rd }}$ Edition. India.

Douglas W.Regalia, (2006), Financial Audit $3^{\text {rd }}$ Edition United States.

G Issellebou-Raad, (200) Managerial Auditing Journal, Volume 15, India

Heramson and Rittenburg, (2003), The Potential Of Internal Auditing $2^{\text {nd }}$ Edition, Network.

Jeffery Ridiey, (2008), Cutting Edge Internal Auditing Planning, $4^{\text {th }}$ Edition United K Ingdom

Joganneskinnfu and Engida Bayou, (2009), Auditing Introduction To Principles And Practices, Ethiopia.

K.H Spencer, (2003), Internal Auditing Hand Book, $3^{\text {rd }}$ Edition India.

Lorry F.Konrath, (1999), Auditing Concepts and Applications $4^{\text {th }}$ Edition, China.

Mihret and W/Yohannis, (2008) Value Added Role of Internal Audit, Ethiopia Case Study Managerial Audit $7^{\text {th }}$ Edition, Ethiopia. 